\title{
GAMBARAN PENGETAHUAN IBU PRIMIGRAVIDA TRIMESTER III TENTANG PERSIAPAN LAKTASI DI PUSKESMAS SLAWI TAHUN 2015
}

\author{
Dwi Santika Putri ${ }^{1}$, Seventina Nurul Hidayah ${ }^{2}$ \\ Email: putri_211194@yahoo.com ${ }^{1}$, seventinanurulhidayah@yahoo.com² \\ ${ }^{12}$ DIII Kebidanan Politeknik Harapan Bersama \\ Jln. Mataram No. 09 Tegal \\ Telp/ Fax (0283) 352000
}

\begin{abstract}
Abstrak
ASI merupakan satu-satunya makanan yang sempurna dan terbaik bagi bayi karena mengandung unsur-unsur gizi yang dibutuhkan oleh bayi untuk pertumbuhan dan perkembangan bayi guna mencapai pertumbuhan dan perkembangan bayi yang optimal. Pengetahuan merupakan dasar untuk terbentuknya tindakan seseorang, sehingga diharapkan jika ibu mempunyai pengetahuan tentang persiapan laktasi maka ibu akan berperilaku sesuai pengetahuan yang didapatkan. Tujuan Penelitian ini adalah untuk mengetahui gambaran pengetahuan ibu primigravida trimester III tentang persiapan laktasi di Puskesmas Slawi Tahun 2015. Penelitian ini merupakan penelitian deskriptif, sampel dalam penelitian ini menggunakan accidental sampling. Hasil Penelitian menunjukkan bahwa sebagian besar responden memiliki tingkat pendidikan SD - SLTP $(53,1 \%)$, berumur 20-35 tahun $(53,1 \%)$, dan tidak bekerja $(100,0 \%)$. Tingkat pengetahuan responden tentang persiapan laktasi sebagian besar berpengetahuan cukup $(64,7 \%)$, dan sebagian besar suami ibu mendukung dalam melakukan persiapan laktasi (56,3\%). Disarankan bagi Ibu hamil untuk dapat lebih meningkatkan kesadaran dalam melakukan persiapan laktasi sedari masa hamil dengan asuhan yang diberikan oleh tenaga kesehatan dan juga lebih banyak mencari informasi mengenai pengetahuan persiapan laktasi di media massa maupun media cetak.
\end{abstract}

Kata Kunci : Pengetahuan, Ibu Primigravida Trimester III, Persiapan Laktasi

\section{Pendahuluan}

Pemberian ASI eksklusif bukan hanya isu nasional namun juga merupakan isu global. Pernyataan bahwa dengan pemberian susu formula kepada bayi dapat menjamin bayi tumbuh sehat dan kuat, ternyata menurut laporan mutakhir UNICEF (Fact About Breast Feeding) merupakan kekeliruan yang fatal, karena meskipun insiden diare rendah pada bayi yang diberi susu formula, namun pada masa pertumbuhan berikutnya bayi yang tidak diberi ASI ternyata memiliki peluang yang jauh lebih besar untuk menderita hipertensi, jantung, kanker, obesitas, diabetes dll. ${ }^{[2]}$

Menyusui sejak dini juga memiliki dampak yang positif bagi ibu, yaitu dapat mengurangi morbiditas dan mortalitas karena proses menyusui akan merangsang kontraksi uterus sehingga mengurangi perdarahan pasca melahirkan (postpartum). Menyusui dalam jangka panjang dapat memperpanjang jarak kelahiran karena masa amenorhoe lebih panjang. ${ }^{[4]}$

Kementrian Kesehatan Republik Indonesia menargetkan cakupan pemberian ASI eksklusif sebesar 80\%. Berdasarkan data yang diperoleh dari profil kesehatan tahun 2012, cakupan pemberian ASI eksklusif secara nasional sebesar 48,62\%. Cakupan ASI eksklusif Provinsi Jawa Tengah tahun 2012 hanya sekitar 25,6\%, menurun dibandingkan tahun 2011 $(45,18 \%){ }^{[2]}$

Data yang diperoleh dari Dinkes Kabupaten Tegal menyebutkan bahwa cakupan ASI eksklusif tahun 2014 adalah $63,09 \%$, sedangkan cakupan ASI eksklusif di Puskesmas Pagerbarang sebesar 69,73\%, cakupan ASI eksklusif di Puskesmas Margasari sebesar 69,13\% dan cakupan ASI eksklusif di Puskesmas Slawi sebesar $68,02 \%$. Jumlah tersebut masih dibawah target Nasional yaitu $80 \%$. Wilayah 
Puskesmas Slawi termasuk strategis berada di wilayah kota dan ditengah wilayah Pemerintahan, serta cakupannya dekat dengan rumah sakit. Namun cakupan ASI eksklusifnya masih belum memenuhi target. Salah satu hal yang menghambat pemberian ASI eksklusif diantaranya adalah rendahnya pengetahuan ibu dan keluarga lainnya mengenai manfaat ASI dan cara menyusui yang benar. ${ }^{[2]}$

Pengetahuan merupakan dasar untuk terbentuknya tindakan seseorang, sehingga diharapkan jika ibu mempunyai pengetahuan tentang persiapan laktasi maka ibu akan berperilaku sesuai pengetahuan yang didapatkan ${ }^{[3]}$. Penelitian ini bertujuan untuk mengetahui gambaran pengetahuan ibu primigravida trimester III tentang persiapan laktasi di Puskesmas Slawi.

\section{Metode Penelitian}

Peneliti menggunakan metode survei deskriptif dengan melihat gambaran pengetahuan ibu primigravida trimester III tentang persiapan laktasi di Puskesmas Slawi Kecamatan Slawi Kabupaten Tegal. Kriteria sampel pada penelitian ini adalah ibu primigravida yang usia kehamilannya 28 sampai 40 minggu, kriteria eksklusi sampel antara lain ibu yang tidak datang ke pelayanan kesehatan serta tidak bersedia menjadi responden, dan didapatkan sampel sebanyak 32 responden.

Penelitian dilakukan dengan menggunakan angket dan metode pengumpulan data dengan membagikan kuesioner yang kemudian dilakukan analisis data menggunakan analisis deskriptif.

\section{Hasil dan Pembahasan}

Penelitian dilakukan pada 32 responden yaitu ibu primigravida trimester III yang memeriksakan kehamilannya di Puskesmas Slawi Kecamatan Slawi Kabupaten Tegal Tahun 2015 dan memenuhi kriteria yang telah ditentukan dalam penelitian ini. Hasil survey menunjukkan ibu primigravida trimester III rata-rata berpendidikan SD SLTP, berumur 20-35 tahun, dan tidak bekerja. Karakteristik responden sangat mendukung suksesnya program ASI eksklusif.
Tabel 1. Karakteristik Responden

\begin{tabular}{|l|c|l|}
\hline $\begin{array}{l}\text { Karakteristik } \\
\text { Responden }\end{array}$ & Jumlah & $\%$ \\
\hline Pendidikan & & \\
\hline Tidak Sekolah & 0 & 0 \\
\hline Pendidikan Dasar & 17 & 53,1 \\
\hline Pendidikan Menengah & 13 & 40,6 \\
\hline Perguruan Tinggi & 2 & 6,3 \\
\hline Umur & & \\
\hline$<20$ Tahun & 8 & 25,0 \\
\hline 20 - 35 Tahun & 17 & 53,1 \\
\hline$>35$ Tahun & 7 & 21,9 \\
\hline Total & 32 & 100 \\
\hline Pekerjaan & 32 & 100 \\
\hline Tidak Bekerja & 0 & 0 \\
\hline Bekerja & & \\
\hline
\end{tabular}

Persiapan menyusui pada periode antenatal adalah persiapan menyusui sejak kala hamil. Proses menyusui sebaiknya sudah dipersiapkan jauh hari sebelum melahirkan. Hal ini penting supaya ibu benar-benar siap, baik secara fisik maupun mental. Kesiapan ini akan mempengaruhi kualitas dan kuantitas ASI. Untuk itu ibu hamil memerlukan nasihat dan saran khususnya dari bidan dan dokter yang dapat menjelaskan tentang persiapan laktasi sehingga ibu dapat lebih siap untuk menyusui bayinya. ${ }^{[3]}$

Pengetahuan merupakan hasil dari tahu, dan hal ini terjadi setelah orang melakukan penginderaan terhadap suatu objek tertentu dalam membentuk tindakan seseorang melalui panca indera manusia yaitu indera penglihatan, pendengaran, penciuman rasa dan raba. ${ }^{[1]}$

Tabel 2. Tingkat Pengetahuan

\begin{tabular}{|l|l|l|}
\hline Variabel & Kategori & Nilai (\%) \\
\hline Tingkat & Kurang & 9,4 \\
Pengetahuan & Cukup & 50,0 \\
& Baik & 40,6 \\
Tingkat & & \\
pengetahuan & Kurang & 59,4 \\
berdasarkan : & Cukup & 28,1 \\
Konsep ASI & Baik & 12,5 \\
& Kurang & 3,1 \\
Persiapan & Cukup & 21,9 \\
psikologis dan & Baik & 75,0 \\
gizi ibu hamil & Kurang & 6,2 \\
& Cukup & 59,4 \\
Pemeriksaan & Baik & 34,4 \\
dan & Kurang & 9,3 \\
perawatan & Cukup & 46,9 \\
payudara & Baik & 43,8 \\
& & \\
Cara menyusui & & \\
yang benar & & \\
\hline
\end{tabular}


Hasil penelitian menunjukkan cakupan pengetahuan ibu primigravida trimester III tentang persiapan laktasi di Puskesmas Slawi tergolong cukup sebanyak 50\%, hal tersebut terjadi karena sebagian besar responden sering melakukan pemeriksaan kehamilan dan diberitahu oleh tenaga kesehatan tentang persiapan laktasi, begitu juga informasi dari saudara, teman sejawat atau ibu kandung responden.

Ditemukan juga kendala yaitu tingkat pengetahuan yang paling rendah terdapat pada konsep ASI dengan sebagian besar berpengetahuan kurang ada 19 responden $(59,4 \%)$. Berdasarkan hasil penelitian tersebut diharapkan bagi tenaga kesehatan untuk lebih menginformasikan tentang konsep ASI agar ibu dapat melakukan persiapan laktasi sedari dini.

Persiapan laktasi tidak selalu hanya pada ibu saja, peran suami juga dibutuhkan. Dalam hal ini dukungan suami penting untuk kehamilan istri karena terkadang istri dihadapkan pada situasi ketakutan dan kesendirian, sehingga suami diharapkan untuk selalu memotivasi dan menemani ibu hamil. Selain itu dukungan yang diberikan suami selama istri hamil juga dapat mengembalikan kepercayaan diri calon ibu dalam mengalami proses kehamilannya.

Tabel 3. Dukungan Suami

\begin{tabular}{|l|l|l|}
\hline Variabel & Kategori & Nilai (\%) \\
\hline Dukungan & Mendukung & 56,3 \\
Suami & Tidak & 43,8 \\
& Mendukung & \\
Tingkat & & \\
pengetahuan & Kurang & 34,4 \\
berdasarkan : & Cukup & 50,0 \\
Dukungan & Baik & 15,6 \\
Informatif & Kurang & 9,4 \\
& Cukup & 59,4 \\
Dukungan & Baik & 31,2 \\
Finansial & Kurang & 0 \\
& Cukup & 0 \\
Dukungan & Baik & 100 \\
Psikologis & & \\
& & \\
\hline
\end{tabular}

Berdasarkan hasil penelitian
menunjukkan bahwa karakteristik
responden berdasarkan dukungan suami,
responden yang suami mendukung ada 18
responden $(56,3 \%)$.
Dukungan suami dapat mempengaruhi
pengetahuan dikarenakan ibu yang

mendapat dukungan suami akan lebih bersemangat dalam mencari informasi baik dari tenaga kesehatan, orang tua, internet, maupun media cetak. Hal tersebut sesuai dengan hasil penelitian yang telah dilakukan, bahwa dari 32 responden ibu yang mendapatkan dukungan psikologis dari suami didapatkan hasil seluruh ibu berpengetahuan baik.

\section{Kesimpulan}

Hasil penelitian menunjukkan cakupan pengetahuan ibu primigravida trimester III tentang persiapan laktasi adalah cukup $(50 \%)$ namun ditemukan $59,4 \%$ ibu memiliki pengetahuan yang rendah terhadap konsep ASI. Serta sebagian besar suami ibu primigravida trimester III mendukung dalam melakukan persiapan laktasi $(56,3 \%)$.

Bidan memiliki peran penting untuk mengoptimalkan dan meningkatkan pelayanan kebidanan khususnya tentang pengetahuan persiapan laktasi dengan cara memberikan penyuluhan dan konseling tentang persiapan laktasi pada saat kunjungan antenatal. Namun bukan hanya bidan sebagai tenaga kesehatan, ibu hamil juga diharapkan dapat lebih meningkatkan kesadaran dalam melakukan persiapan laktasi sedari masa hamil dengan asuhan yang diberikan oleh tenaga kesehatan dan juga lebih banyak mencari informasi pengetahuan persiapan laktasi di media massa maupun media cetak.

\section{Daftar Pustaka}

[1] Notoatmodjo, Soekidjo. 2007. Promosi Kesehatan dan Ilmu Perilaku. Jakarta : Rineka Cipta.

[2] Dinas Kesehatan Provinsi Jawa Tengah. 2012. Buku Profil Kesehatan Provinsi Jawa Tengah Tahun 2012. Semarang : Dinas Kesehatan Provinsi Jawa Tengah.

[3] Maryunani, Anik. 2012. Inisiasi Menyusu Dini, ASI Eksklusif dan Manajemen Laktasi. Jakarta : TIM.

[4] Badan Penelitian dan Pengembangan Kesehatan Kementrian Kesehatan RI. 2013. Riset Kesehatan Dasar. Jakarta :Badan Penelitian dan Pengembangan Kesehatan Kementrian Kesehatan RI. 